\title{
Practical Study for the Effect of Speed, Direction of Acceleration and Type of Machine on Vibrations Transferred to the Steering Wheel Horticulture Tractor Type (Goldoni)
}

\author{
Ghazwan Ahmed Dahham, Saad Tawfik Muhamed, Shamel Mohammed Saleh \\ Department of Agricultural Machines and Equipment, University of Mosul, Mosul, Iraq \\ Email: ghazwanagr@uomousl.edu.iq, saad.t.m@uomosul.edu.iq,eng.sh.hassn@uomosul.edu.iq
}

How to cite this paper: Dahham, G.A., Muhamed, S.T. and Saleh, S.M. (2019) Practical Study for the Effect of Speed, Direction of Acceleration and Type of Machine on Vibrations Transferred to the Steering Wheel Horticulture Tractor Type (Goldoni). Engineering, 11, 48-58. https://doi.org/10.4236/eng.2019.111005

Received: November 28, 2018

Accepted: January 25, 2019

Published: January 28, 2019

Copyright $\odot 2019$ by author (s) and Scientific Research Publishing Inc. This work is licensed under the Creative Commons Attribution International License (CC BY 4.0).

http://creativecommons.org/licenses/by/4.0/

\begin{abstract}
Field an experiment was carried out in the farms of Agriculture and forestry academy at University in Nineveh. The research was conducted to investigate a practical study for the effect of four forward speeds $(1.9,2.6,3.8$ and $4.7 \mathrm{~km} / \mathrm{hr}$.) and three acceleration direction of axes lateral, longitudinal and vertical, and two types machines control (Mower and Rotovators) on the vibrations transferred to the steering wheel horticulture tractor type (Goldoni). The vibration points on the handgrip were calculated and tested. Root mean square acceleration (RMS), given in $\mathrm{m} / \mathrm{sec}^{2}$, was calculated. Results showed increased acceleration vibration of the three directions (longitudinal, lateral and vertical) transferred to the steering wheel tractor by increased forward speed. The Mower score recorded the highest acceleration vibration for the three directions of Rotovators. The levels of vibration emitted from tractor to hand an operator during the experiment was high comparing with standard mechanical vibration. Handgrip vibration intensity in the vertical direction is bigger than the lateral and longitudinal direction. The total vibration evaluating was denoted as the square root mean of the three sum value (lateral, longitudinal and vertical) directions. The paper purpose was measuring and analyzing vibration level transferred to the steering wheel and reduces the machine vibration. This paper is helpful for design in order to increase the develop safety systems in easy and economical way.
\end{abstract}

\section{Keywords}

Ergonomics, Vibrations, Hand-Transmitted Vibration, Tractor 


\section{Introduction}

Workers often suffer in heavy, especially those who are using. The equipment with the nature of the seismic events of significant health problems was encouraged to study and analyze and measure the vibration of workers in this area, which is one of the most interesting engineering applications. This physical factor that acts on the human body is vibration which transmits the mechanical energy from sources of oscillation [1]. Vibration can effect in different way to the operators; machine operators are always meeting two different types of vibration: vibrations effect to the whole-body produce through seat or floor and feet, and vibration which produced by the hand-grip. Both forms of vibration can effect on the operator which reduce on his job performance and health [2]. Farm tractors and other earth-moving equipment contribute to some of the most common, prolonged, and severe occupational exposures of vehicle vibration among equipment operators [3]. Disturbances in finger blood flow, and in neurological and motor functions of the hand and arm can produce by excessive exposure to hand-transmitted vibration. It has been estimated that $1.7 \%-3.6 \%$ of the American and European workers are exposed to potentially harmful hand transmitted vibration [4]. The European list of recognized occupational diseases inserted these disorders [5]. The term "handarm vibration syndrome" (HAVS) is a case resulting with the exposure of machincal vibrating transmitted through hand and arm that affect in disorders vascular, neurologic, and musculoskeletal. Although that are a very important issue and serious in many nation, small concern are paid to that. Nearly any user of agricultural tools is exposed to "whole body vibration "or" hand arm vibration". Even people on work that seems simple careers such as cutting the grass in the garden by the machine or driving the tractor in the orchards can be exposed to sudden vibration; especially vibration resulted from the handle to the driver's hands. This vibration was known as a trouble [6]. Vibration in tractor depends on many factors velocity of tractor, topography of field, tractor condition and design tractor and configuration which is by dynamic response [7]. Vibration power resulting to use a lot of different types of agriculture's tools can cause hand vibration in the tractor driver, and used density of these tools can affect the nervous system such as changes in tendons, tissue diseases, muscles, bones and the vascular injury which also results lower blood flow that is the most common complication of this type of vibration which can produce white fingers [8]. The vibration entering to the operator hand not only causes health problems, but also lowers the driver working skills and sensation; using this type of tractors is very common in small and medium orchards and vegetable farms; these tractors considered easy to use and the cheapness, and these types known as small size tractor or single-axle tractor can be used in many agricultural operations like harvesting, plant protection, irrigation, threshing, and transportation [9]. Human exposure to mechanical vibration may represent a significant risk factor for exposed workers in the agricultural sector, with particular reference to the operators driving tractors [10]. 


\section{Material and Methods}

A field experiment was conducted at experimental field of agriculture and Forestry College at the University of Mosul in the north west of the city of Mosul.

\subsection{Tasted Tractor}

The implementation of the horticulture Goldoni tractor search type is shown in Table 1.

Used two types control machines (Mower) width work $120 \mathrm{~cm}$ and (Rotovators) width work $85 \mathrm{~cm}$ as shown in (Figure 1).

\subsection{Soil}

Soil type was clay-silt as shown in (Table 2).

\subsection{The Experiment}

Used vibration meter type (Adash4900-vabrio M) to measure the vibration force Table 1. Tasted tractor-technical characteristics.

\begin{tabular}{cc}
\hline \multicolumn{2}{c}{ Technical characteristics } \\
\hline Type & Goldoni $10 \mathrm{~s}$ \\
Model & Professional two-wheeled tractor 3200 \\
Rated power & $6.4 \mathrm{KW} / 8.5 \mathrm{HP}$ \\
Number of cylinders & 1 \\
Nominal rate & $3600 \mathrm{rpm}$ \\
Cooling & Air \\
Gear & 4 normal, 4 low \\
Length (front bumper/rear handle bar) & $1795 \mathrm{~mm}$ \\
Weight with wheels and rotary cultivator & $153 \mathrm{Kg}$
\end{tabular}

Set of wheels $5.00 \times 10^{\prime \prime}$ on adjustable disc Obtainable widths: $533 \mathrm{~mm}-553 \mathrm{~mm}-621 \mathrm{~mm}-661 \mathrm{~mm}$

Clutch Dry monodisc, diameter 4.3"

Type transmission

Security Mechanical traction, with endless screw and oil bath gears

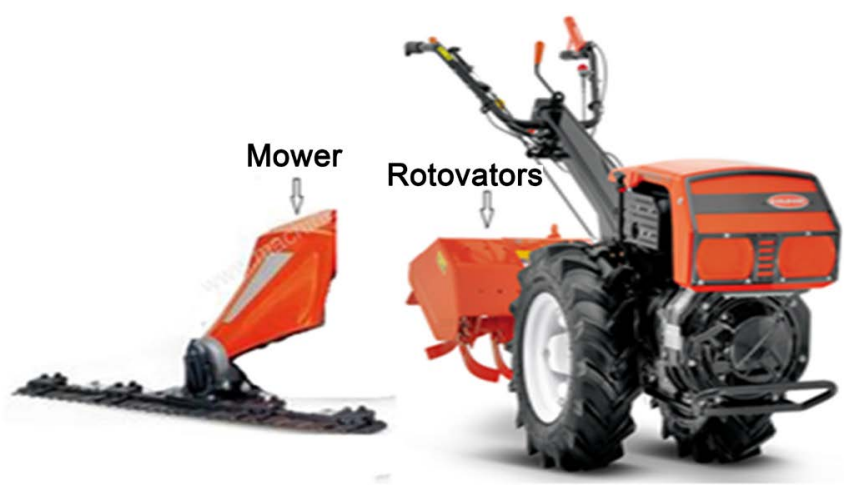

Figure 1. Horticulture tractor type (Goldoni) 
of the three orthogonal directions (longitudinal: $Y_{h}$ ), (vertical: $Z_{h}$ ) and (lateral: $\mathrm{X}_{\mathrm{h}}$ ), hand grip shown in (Figure 2).

The device consists of sensor vibration which contains the introduction of the magnet secures the required surface measurement relates to mainstream sensor rattled by wire measurement device that contains the digital display shows the values of the vibration. The vibration was sensitive side and portrait layout according to the system for the hand as shown in the (Figure 3).

The quantity used to describe the magnitude of vibration shall be the frequency weighted acceleration in meters per second squared $\left(\mathrm{m} / \mathrm{s}^{2}\right)$, expressed as a rootmean-square. As, it is important that for additional purposes frequency spectra must be acquire, the frequency weighted acceleration can get using ISO 5008:

Table 2. Mean characteristics of the soil at the site of the experiment.

\begin{tabular}{ccc}
\hline & Mean characteristics & \\
\hline Soil & Value & Unit \\
\hline Sand & 15.4 & $(\%)$ \\
Silt & 40.0 & $(\%)$ \\
Clay & 44.6 & $(\%)$ \\
Soil bulk density & 1.329 & $\left(\mathrm{Mg} / \mathrm{m}^{3}\right)$ \\
Soil moisture content & 13.8 & $(\%)$ \\
Cone index & 12.45 & $\left(\mathrm{~kg} / \mathrm{cm}^{2}\right)$
\end{tabular}

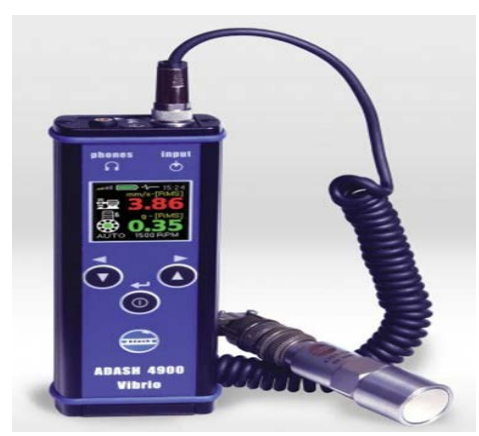

Figure 2. Adash4900-vabrio.

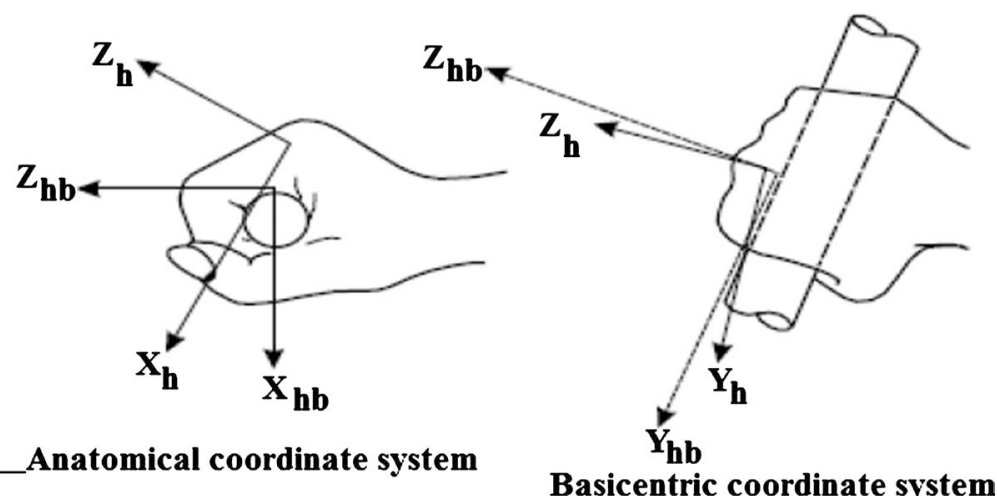

Figure 3. Draw of hand grip axises. 
2002 was estimate by analyzing the range of $1 / 3$ of octave using acceleration values:

$$
a_{h . w}=\left[\sum_{j=1}^{n}\left(w_{j} a_{w . j}\right)^{2}\right]^{1 / 2}
$$

where: $a_{h . w}$ frequency weighted acceleration in the direction $i(i=x, y$ or $z), a_{w j}$ is the acceleration acquired $\left(\mathrm{m} / \mathrm{sec}^{2}\right)$ and $W_{j}$ is dimensionless weighting factor as given in (Figure 3) (Figure 4).

It is also important vibration measure location shall be as close together as possible that significantly affect the measured value.

In consensus with the indicated ISO standards, the three directions of an orthogonal coordinate system, in which the vibration accelerations should be accounted, were as follows: $\mathrm{z}$-axis, $\mathrm{x}$-axis and $\mathrm{y}$-axis.

In accordance with ISO 5349 the assessment of vibration exposure depends on a quantity that combines all three axes. This is weighted acceleration sum or vibration total value it is defined as the root-mean-square of the three constituent values:

$$
a_{h v}=\sqrt{a_{h w x}^{2}+a_{h w y}^{2}+a_{h w z}^{2}}
$$

where: $a_{h w x} ; a_{h w y} ; a_{h w z}$ are frequency weighted acceleration values for the single axes.

The vibration exposure depends on the duration of the exposure and on the magnitude of the vibration total value. Daily exposure duration is the total time for which the hands are exposed to vibrations during the working day. The daily vibration exposure should be expressed in terms of the 8-hour energy-equivalent acceleration or frequency-weighted vibration total value:

$$
A(8)=a_{h v} \sqrt{\frac{T}{T_{0}}}
$$

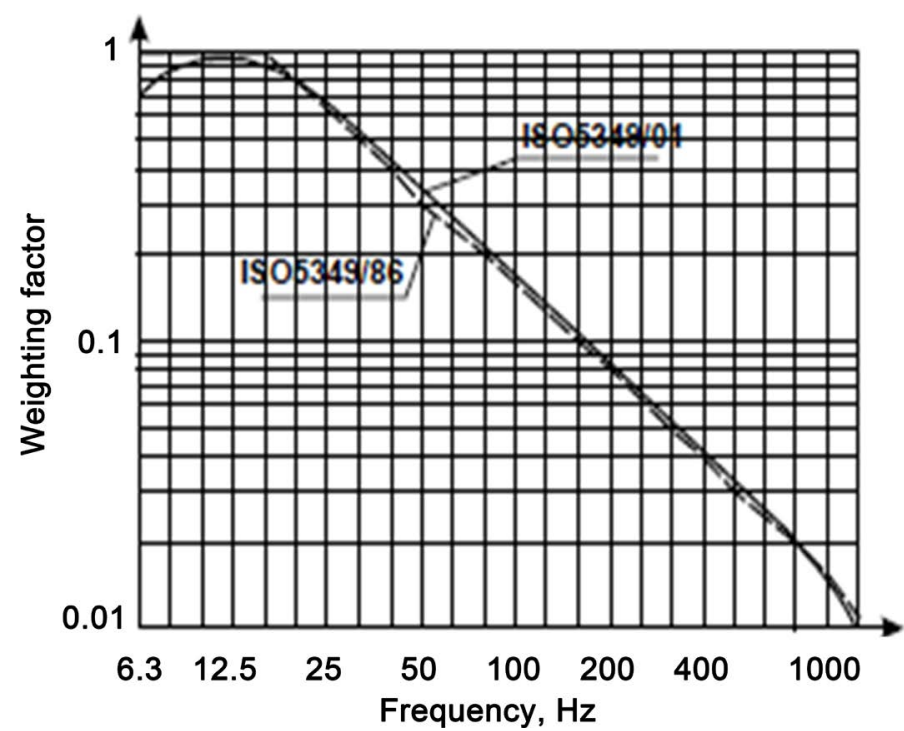

Figure 4. Scheme frequency weighting factor. 
where: $T$ is the total daily duration of the exposure (sec), and $T_{0}$ is the reference duration of $8 \mathrm{~h}$.

When total daily vibration exposure contains many process, with various vibration magnitudes, the daily vibration exposure, $A$ ( 8 hours) shall be calculates using:

$$
A(8)=\sqrt{\frac{1}{T_{0}} \sum_{i=1}^{n} a_{h v i}^{2} x T_{i}}
$$

where $a_{h v i}$ is the vibration gross rate for $i$ the process, $n$ is number of single exposures, and $T_{i}$ is the period of $i$ the process.

The total daily vibration exposure calculated approximately 3.5 (hr.) working day the operator spends, in Mower, and spends approximately 2 (hr.) in Rotovators:

$$
\begin{aligned}
& A(8) \text { For } . L 1=\sqrt{\frac{1}{28800}\left(12600 \times 21.84^{2}+7200 \times 20.56^{2}\right)} \\
& =17.73 \mathrm{~m} / \mathrm{sec}^{2} \\
& A(8) \text { For } . L 2=\sqrt{\frac{1}{28800}\left(12600 \times 27.84^{2}+7200 \times 26.65^{2}\right)} \\
& =22.72 \mathrm{~m} / \mathrm{sec}^{2} \\
& A(8) \text { For } . L 3=\sqrt{\frac{1}{28800}\left(12600 \times 33.54^{2}+7200 \times 32.15^{2}\right)} \\
& =27.39 \mathrm{~m} / \mathrm{sec}^{2} \\
& A(8) \text { For } . L 4=\sqrt{\frac{1}{28800}\left(12600 \times 39.78^{2}+7200 \times 38.55^{2}\right)} \\
& =32.61 \mathrm{~m} / \mathrm{sec}^{2}
\end{aligned}
$$

Weighted acceleration sum (WAS), forward speed, vibration value for all the direction, for tow machines, and their presentation are shown in Table 3 and Table 4.

\section{Results and Discussion}

Note from Figure 5 and Figure 6 the vibration acceleration of the three axes (Longitudinal, Lateral, Vertical) increase as the forward speeds of the tractor increases that may be due to the increase the frequency of vibration of the agricultural tractor when increasing forward speed, where the fourth forward speed highest recorded vibration acceleration three axles were the results $\left(19.20,13.80,32.00 \mathrm{~m} / \mathrm{sec}^{2}\right)$ respectively. While the first front speed less than vibration acceleration of three axles were the results $\left(9.40,8.10,16.40 \mathrm{~m} / \mathrm{sec}^{2}\right)$ respectively. These results agree with [11] who found the vibration acceleration increase as the forward speeds of the tractor increases.

As indicated in Figure 7 the Mower recorded the highest vibration acceleration of the three axes (Longitudinal, Lateral, Vertical) were the results (14.94, 11.35, 24.37) $\mathrm{m} / \mathrm{sec}^{2}$ respectively, while Rotovators less than vibration acceleration of three axles were the results $(14.17,10.72,23.52) \mathrm{m} / \mathrm{sec}^{2}$ respectively, that may 
Table 3. WAS mean value for Mower $\left(\mathrm{m} / \mathrm{sec}^{2}\right)$.

\begin{tabular}{|c|c|c|c|c|c|c|}
\hline \multirow{3}{*}{ Type Machine } & \multicolumn{6}{|c|}{ Mower } \\
\hline & \multirow{2}{*}{ Gear box No. } & \multirow{2}{*}{$\begin{array}{l}\text { Accelerate } \\
\text { direction }\end{array}$} & \multicolumn{3}{|c|}{ Measuring number } & \multirow{2}{*}{ Mean value } \\
\hline & & & 1 & 2 & 3 & \\
\hline & \multirow{4}{*}{$\mathrm{L} 1$} & $\mathrm{x}$ & 10.40 & 10.20 & 10.00 & 10.20 \\
\hline & & $\mathrm{y}$ & 8.50 & 8.30 & 9.00 & 8.60 \\
\hline & & $\mathrm{z}$ & 17.40 & 17.50 & 17.00 & 17.30 \\
\hline & & WAS & & & & 21.84 \\
\hline & \multirow{4}{*}{$\mathrm{L} 2$} & $\mathrm{x}$ & 13.40 & 13.0 & 14.00 & 13.47 \\
\hline & & $\mathrm{y}$ & 10.50 & 10.80 & 10.80 & 10.70 \\
\hline & & $\mathrm{z}$ & 21.60 & 21.40 & 22.70 & 21.90 \\
\hline & & WAS & & & & 27.84 \\
\hline & \multirow{4}{*}{ L3 } & $\mathrm{x}$ & 16.50 & 16.90 & 17.00 & 16.80 \\
\hline & & $\mathrm{y}$ & 12.50 & 12.20 & 12.20 & 12.30 \\
\hline & & $\mathrm{z}$ & 26.00 & 26.10 & 26.80 & 26.30 \\
\hline & & WAS & & & & 33.54 \\
\hline & \multirow{4}{*}{$\mathrm{L} 4$} & $\mathrm{x}$ & 19.50 & 19.30 & 18.80 & 19.20 \\
\hline & & $\mathrm{y}$ & 13.50 & 13.90 & 14.00 & 13.80 \\
\hline & & $\mathrm{z}$ & 31.80 & 32.00 & 32.20 & 32.00 \\
\hline & & WAS & & & & \\
\hline
\end{tabular}

$\mathrm{L} 1=1.9 \mathrm{~km} / \mathrm{h} ; \mathrm{L} 2=2.6 \mathrm{~km} / \mathrm{h} ; \mathrm{L} 3=3.8 \mathrm{~km} / \mathrm{h} ; \mathrm{L} 4=4.7 \mathrm{~km} / \mathrm{h}$.

Table 4. WAS mean value for Rotovators $\left(\mathrm{m} / \mathrm{sec}^{2}\right)$

\begin{tabular}{|c|c|c|c|c|c|c|}
\hline \multirow{3}{*}{ Type machine } & \multicolumn{6}{|c|}{ Rotovators } \\
\hline & \multirow{2}{*}{ Gear box No. } & \multirow{2}{*}{$\begin{array}{c}\text { Accelerate } \\
\text { direction }\end{array}$} & \multicolumn{3}{|c|}{ Measuring number } & \multirow{2}{*}{ Mean value } \\
\hline & & & 1 & 2 & 3 & \\
\hline & \multirow{4}{*}{$\mathrm{L} 1$} & $\mathrm{x}$ & 9.50 & 9.20 & 9.50 & 9.40 \\
\hline & & $\mathrm{y}$ & 8.00 & 8.20 & 8.10 & 8.10 \\
\hline & & $\mathrm{z}$ & 16.60 & 16.30 & 16.30 & 16.40 \\
\hline & & WAS & & & & 20.56 \\
\hline & \multirow{4}{*}{$\mathrm{L} 2$} & $\mathrm{x}$ & 13.00 & 12.80 & 13.20 & 13.00 \\
\hline & & $\mathrm{y}$ & 9.90 & 9.60 & 9.90 & 9.80 \\
\hline & & $\mathrm{z}$ & 21.20 & 21.00 & 21.10 & 21.10 \\
\hline & & WAS & & & & 26.65 \\
\hline & \multirow{4}{*}{ L3 } & $\mathrm{x}$ & 15.60 & 15.90 & 16.10 & 15.87 \\
\hline & & $y$ & 11.50 & 11.90 & 11.70 & 11.70 \\
\hline & & $\mathrm{z}$ & 25.50 & 25.20 & 25.50 & 25.40 \\
\hline & & WAS & & & & 32.15 \\
\hline & \multirow{4}{*}{$\mathrm{L} 4$} & $\mathrm{x}$ & 18.20 & 18.60 & 18.40 & 18.40 \\
\hline & & $\mathrm{y}$ & 13.20 & 13.50 & 13.20 & 13.30 \\
\hline & & $\mathrm{z}$ & 31.30 & 31.00 & 31.30 & 31.20 \\
\hline & & WAS & & & & 38.55 \\
\hline
\end{tabular}

$\mathrm{L} 1=1.9 \mathrm{~km} / \mathrm{h} ; \mathrm{L} 2=2.6 \mathrm{~km} / \mathrm{h} ; \mathrm{L} 3=3.8 \mathrm{~km} / \mathrm{hl} ; \mathrm{L} 4=4.7 \mathrm{~km} / \mathrm{h}$. 


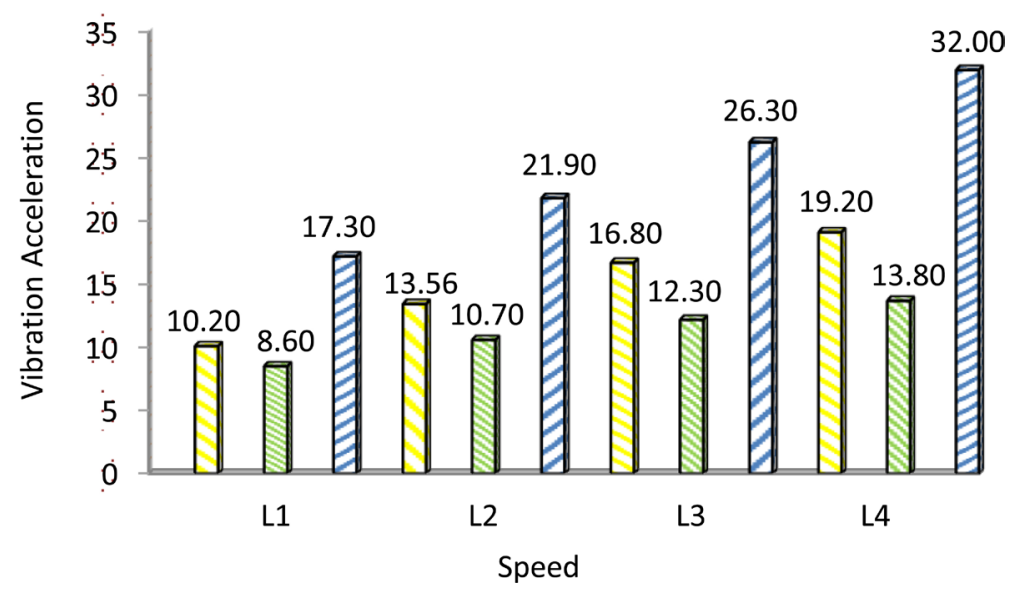

Figure 5. Effect Speed $\left(\mathrm{km} / \mathrm{hr}\right.$.) in Vibration Acceleration $\left(\mathrm{m} / \mathrm{sec}^{2}\right)$ three axes $(\mathrm{X}, \mathrm{Y}, \mathrm{Z})$ Mower L1 $=1.9 \mathrm{~km} / \mathrm{hr}$., L2 $=2.6 \mathrm{~km} / \mathrm{hr}$., L3 $=3.8 \mathrm{~km} / \mathrm{hr}$., L4 $=4.7 \mathrm{~km} / \mathrm{hr}$.

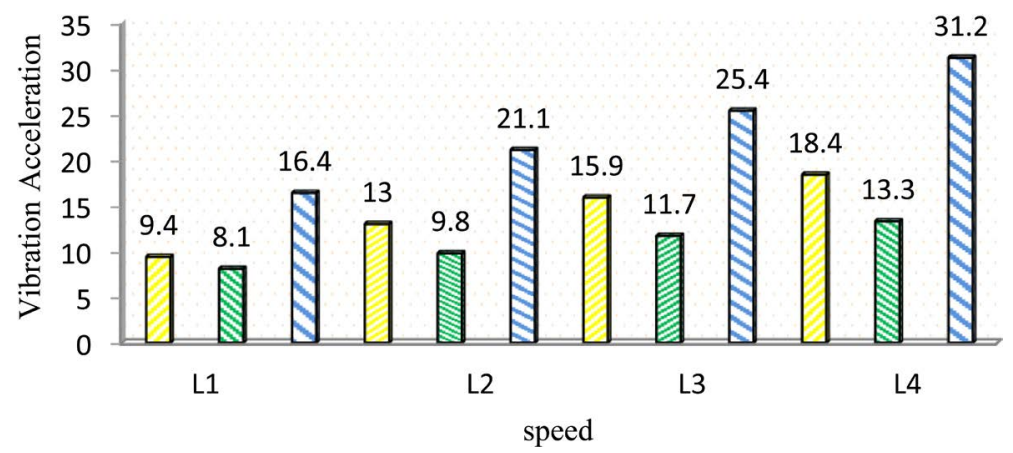

Figure 6. Effect Speed (km/hr.) in Vibration Acceleration $\left(\mathrm{m} / \mathrm{sec}^{2}\right)$ three axes $(\mathrm{X}, \mathrm{Y}, \mathrm{Z})$ Rotovators. L1 $=1.9 \mathrm{~km} / \mathrm{hr}$., L2 $=2.6 \mathrm{~km} / \mathrm{hr}$., L3 $=3.8 \mathrm{~km} / \mathrm{hr}$., $\mathrm{L} 4=4.7 \mathrm{~km} / \mathrm{hr}$.

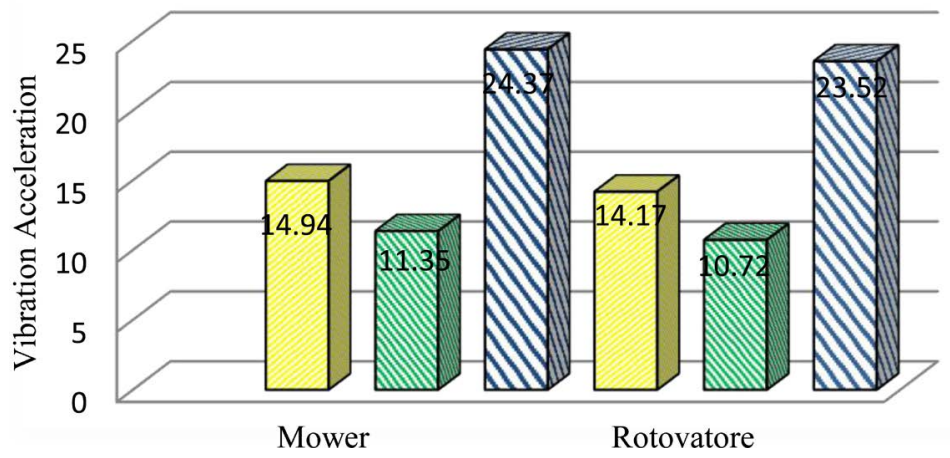

Figure 7. Effect Types Machines in Vibration Acceleration $\left(\mathrm{m} / \mathrm{sec}^{2}\right)$ three axes $(X, Y, Z)$. $\mathrm{L} 1=1.9 \mathrm{~km} / \mathrm{hr}$., L2 $=2.6 \mathrm{~km} / \mathrm{hr}$., L3 $=3.8 \mathrm{~km} / \mathrm{hr}$., L4 $=4.7 \mathrm{~km} / \mathrm{hr}$.

be due to the Mower consider equipment to control the Plant Holt through increased dramatic inequalities in the soil, leading to a decline in the front of the tractor speed and increase the effectiveness of the force in the soil vibration attenuation while Rotovators consider equipment to control the Plant Holt on the soil surface without depth in the soil. These results agree with [12] and [13] who reported that.

Figure 8 shows the interaction between Mower and forward speed (L1, L2, 


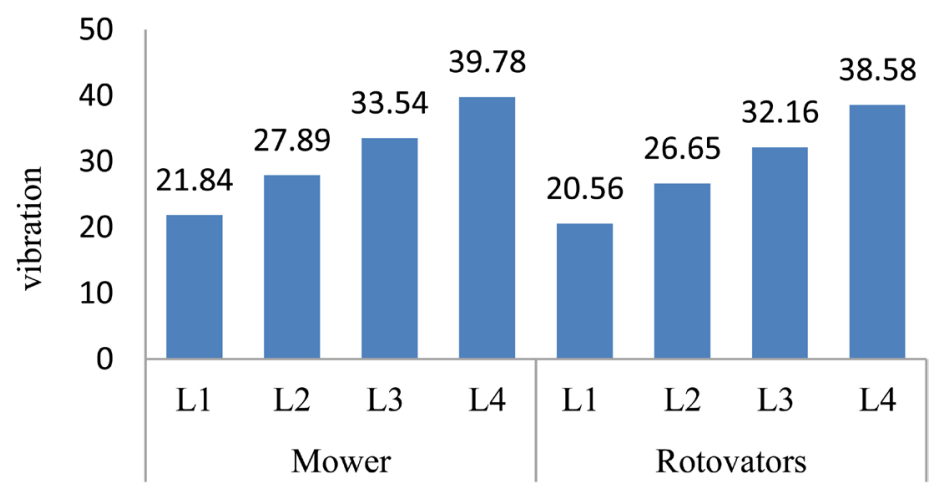

Figure 8. Effect Speed (km/hr.) and Types Machines in Vibration (Hz). L1 $=1.9 \mathrm{~km} / \mathrm{hr}$., $\mathrm{L} 2=2.6 \mathrm{~km} / \mathrm{hr}$., $\mathrm{L} 3=3.8 \mathrm{~km} / \mathrm{hr}$., $\mathrm{L} 4=4.7 \mathrm{~km} / \mathrm{hr}$.

Table 5. Effect Speed (km/hr.), Types Machines and acceleration direction $\left(\mathrm{m} / \mathrm{sec}^{2}\right)$.

\begin{tabular}{ccccc}
\hline \multirow{2}{*}{ Types machines } & Forward speeds & \multicolumn{3}{c}{ Acceleration direction } \\
\cline { 3 - 5 } & & $\mathrm{X}$ & $\mathrm{Y}$ & $\mathrm{Z}$ \\
\hline \multirow{3}{*}{ Mower } & L1 & 10.2 & 8.60 & 17.30 \\
& L2 & 13.56 & 10.70 & 21.90 \\
L3 & 16.80 & 12.30 & 26.30 \\
Rotovators & L4 & 19.20 & 13.80 & 32.00 \\
& L1 & 9.40 & 8.10 & 16.40 \\
& L2 & 13.00 & 9.80 & 21.10 \\
& L3 & 15.90 & 11.70 & 25.40 \\
& L4 & 18.40 & 13.30 & 31.20 \\
\hline
\end{tabular}

L3, L4) highest recorded total vibration were the results $(21.84,27.89,33.54$, 39.79) $\mathrm{Hz}$ respectively, while the interaction between the Rotovators and forward speed (L1, L2, L3, L4) less value recorded total vibration were the results $(20.56,26.65,32.16,38.58) \mathrm{Hz}$ respectively. It is clear from this the Mower with the fourth speed record the highest value, while the Rotovators with the first speed record the less value.

As indicated in Table 5, the Mower with forward speeds (L1, L2, L3, L4) and acceleration direction $(\mathrm{X}, \mathrm{Y}, \mathrm{Z})$ highest recorded vibration, while the Rotovators with forward speed (L1, L2, L3, L4) and acceleration direction (X, Y, $\mathrm{Z})$ less value recorded vibration and also shows the Mower with the fourth (L4) forward speeds with acceleration direction $(Z)$ highest recorded vibration was the results $(32.00) \mathrm{m} / \mathrm{sec}^{2}$, while the Rotovators with the first (L1) forward speeds with acceleration direction (Y) less value recorded vibration was the results $(8.10) \mathrm{m} / \mathrm{sec}^{2}$.

\section{Conclusions}

- The velocity of the tractor had the strongest effect on the vibration transmitted from the steering wheel to the hands of the driver from all axis. 
- Hand-arm vibration intensity is greater in the vertical direction than the lateral and longitudinal direction.

- Like these value acceleration (rms) effects on driver and caused discomfort, will produce finger blanching, tired, and less performance and not completely control operation to the tractor by driver, and also appear the type of machine influence on the vibration.

\section{Conflicts of Interest}

The authors declare no conflicts of interest regarding the publication of this paper.

\section{References}

[1] Bovenzi, M. (1997) Hand Transmitted Vibration: Encyclopedia of Occupational Health and Safety. 4th Edition, International Labor Office, 1-50.

[2] Issever, H., Aksoy, C., Sabuncu, H. and Karan, A. (2003) Vibration and Its Effects on the Body. Medical Principles and Practice, 12, 34-38.

https://doi.org/10.1159/000068155

[3] ISO (2002) Agricultural Wheeled Tractors and Field Machinery Measurement of Whole-Body Vibration of the Operator. International Standardization Organization, ISO5008.

[4] Kacian, N. (1997) A Statistical Report on Occupational Diseases in Croatia. Work Safety 2. Journal Work and Safety, 2, 271.

[5] ISO (2001) Mechanical Vibration Measurement and Evaluation of Human Exposure to Hand-Transmitted Vibration Part 1: General Requirements. ISO, Geneva, ISO5349-1.

[6] Goglia, V. and Gospodaric, Z. (2002) Driver's Exposure to Hand Transmitted Vibration from the Steering Wheel of the LPKT 40 Tractor. The 30 th International Symposium on Agricultural Engineering, Opatija, 12-15 March 2002, 163-170.

[7] HSE, Health and Safety Executive (2008) Health and Hazards from Whole-body Vibration Caused by Mobile Agricultural Machinery. HSE Sheet No 20.

http://www.hse.gov.uk/index.htm

[8] Mohsen, F., Lorestani, A.N., Rabbani, H. and Javadikia, P. (2012) Measurement and Analysis of Vibration of Operator in Universal 650, Massey Ferguson 285 \& MF 299 Tractors. International Journal of Mechanics and Applications, 2, 88-92. https://doi.org/10.5923/j.mechanics.20120205.06

[9] Fabbri, A., Cevoli, C. and Cantalupo, G. (2017) A Method for Handlebars Ballast Calculation in Order to Reduce Vibrations Transmissibility in Walk behind Tractors. Journal of Agricultural Engineering, 48, 81-87. https://doi.org/10.4081/jae.2017.599

[10] Vallone, M., Bono, F., Quendler, E., Febo, P. and Catania, P. (2016) Risk Exposure to Vibration and Noise in the Use of Agricultural Track-Laying Tractors. Annals of Agricultural and Environmental Medicine, 23, 591-597. https://doi.org/10.5604/12321966.1226852

[11] Hamid Ahmed, A.A. (2013) Vibration Efficiency of Grass Mower. The Iraqi Journal of Agricultural Science, 44, 540-552.

[12] A-Jarrah, M.A. (2011) Effect of Tires Inflation Pressure, Tillage Depth and Forward Speed on Some Field Performance Criteria of Tractor. Mesopotamia Journal of 
Agriculture, 39, 188-197.

[13] AlMafrachi, A.A.H. (2009) The Influence of Certain Standard Operating Conditions in the Vibrations and Performance Indicators Tractor Type of Antar 71 and Type of New Holland 80 66-S. Master Department of Agricultural Mechanization, Faculty of Agriculture, University of Baghdad, Baghdad. 